\title{
The tenacity of trust in petrochemical communities: Reckoning with risk on the Fawley Waterside (1997-2019)
}

EPE: Nature and Space

(C) The Author(s) 2021

(c) (i)

Article reuse guidelines: sagepub.com/journals-permissions DOI: I0.1 I77/25|484862II 045367 journals.sagepub.com/home/ene

\author{
David Brown (D), Alice Mah \\ University of Warwick, UK
}

\section{Gordon Walker}

Lancaster University, UK

\begin{abstract}
Around the world, people living close to polluting industries have different perceptions of the risks of toxic exposure, ranging from anger to acceptance to denial. We draw attention to a case with relatively high levels of social trust, but also relatively high levels of risk perception: the communities living adjacent to the Fawley (UK) oil refinery and petrochemical complex, a site that has been operated by Esso since the early 1950s.

Our findings are based on a novel comparative analysis of two qualitative studies of local risk perceptions in Fawley conducted more than two decades apart in 1997 and 2019, incorporating focus group and individual interviews with residents, alongside documentary analysis and stakeholder interviews. Perceptions of risk and trust in the local polluting industry have fluctuated over the years, with unease never far from the surface as industrial employment has slowly contracted. Yet overall, the picture in 2019 was not too dissimilar from that in 1997: while community-industry relations were strained amidst periodic risk incidents and a sense of decline, a cautious sense of trust in the polluting enterprise had endured, based on a delicate balance of heritage, risk, and recognition. We draw attention to the residents' careful reckoning with risks over time and the tenacity of social trust as an act of negotiation that took risk into account but also included other important factors such as recognition and reciprocity. Local risk perceptions in Fawley are closely bound up with the residents' shared industrial heritage and enduring perceptions of Esso as a 'good neighbour'. Our longitudinal analysis allowed us to reflect on changes over time in Fawley, providing greater temporal depth to the risk perception literature.
\end{abstract}

\section{Keywords}

Trust, risk perceptions, industrial hazards, pollution, environmental justice

\section{Corresponding author:}

David Brown, Department of Sociology, University of Warwick, Coventry, UK.

Email: browndI7@hotmail.co.uk 


\section{Introduction}

Travelling along the main road in the town of Holbury, past the former Esso Social Club, you can glimpse the sprawling petrochemical complex at Fawley through the holes in its greenbelt (see Figure 1). The largest oil refinery and petrochemical plant in the UK, and the second largest in Europe, the ExxonMobil (Esso) site at Fawley resembles a small city of industrial towers, tanks, and flares. Like many other large industrial sites, Fawley is surrounded by a tall electric fence with signs warning off intruders. However, it also has a further layer of insulation: a greenbelt of thick conifers and forest growth, designed when the refinery was built in 1951 to hide the industry from the community. Hemmed in by industry on one side, and the New Forest National Park on the other, residential neighbourhoods grew up around the prosperous industry in the 1950s and 1960s, echoing models of company garden towns. These post-war working-class communities developed close social, economic, and cultural ties with Esso, fostering a strong local sense of trust in industry. Remarkably, as this article will discuss, the local trust has endured over the decades, despite periodic accidents and ongoing complaints about the risks of living with pollution.

The Fawley petrochemical complex, with its large-scale storage of flammable, explosive, and toxic materials and ongoing polluting emissions, poses a number of risks to local residents' safety, health and well-being. The global petrochemical industry is a significant source of toxic air pollution, most notably the release of benzene, toluene, ethylbenzene and xylene (BTEX) compounds, which are known carcinogens (Jephcote and Mah, 2019). Exposure to toxic petrochemicals has been associated with a range of illnesses, including cancer, respiratory conditions and neurological damage (WHO, 2014). Jephcote and Mah (2019) have highlighted that despite air quality regulations, many European citizens living in close proximity to petrochemical facilities are exposed to unsafe levels of benzene emissions, which are associated with increased mortality rates for nearby residential populations. Moreover, despite advanced emergency response management, the threat of accidents and explosions at refinery and petrochemical sites remains.

This article is based on a novel comparative analysis of two qualitative studies of local risk perceptions in Fawley conducted more than two decades apart in 1997 and 2019, including focus group interviews, individual qualitative interviews and documentary analysis. Both research projects explored perceptions of local risk and industry in Fawley. The 1997 research in Fawley formed a part of a larger, collaborative UK-wide research project that was designed to provide 'a better understanding of the nature and dynamics of public perceptions of the risks associated with major hazard sites' (Walker et al., 1998). The 2019 Fawley study was a part of the 'Toxic Expertise' project, a large European Research Council-funded project examining the global petrochemical industry in relation to corporate social responsibility and environmental justice, including case studies in the US, China and Europe. While the 2019 research was not conducted as a repeat study, it drew inspiration from the 1997 study, particularly the use of focus groups.

One of the most striking initial findings of the 2019 research was how little seemed to have changed since the 1997 study. On the basis of these findings, we decided to collaborate on a comparative analysis of qualitative data from both studies to reflect on changes over time, providing greater temporal depth to the risk perception literature. In 1997, public trust in industry was relatively strong, with many positive associations based on the historical role of Esso in the development of the local communities and as an employer. There were also some signs of eroded trust, with a number of public concerns about pollution and the risk of accidents. Despite a number of further accidents, risks, and controversies in the next two decades, the same was true in 2019. What accounts for this tenacity of trust, however fragile?

Between the recurrent concerns over risks and the gradual contraction of industrial employment in the 1980s and 1990s, the implicit social contract between communities and industry in Fawley 


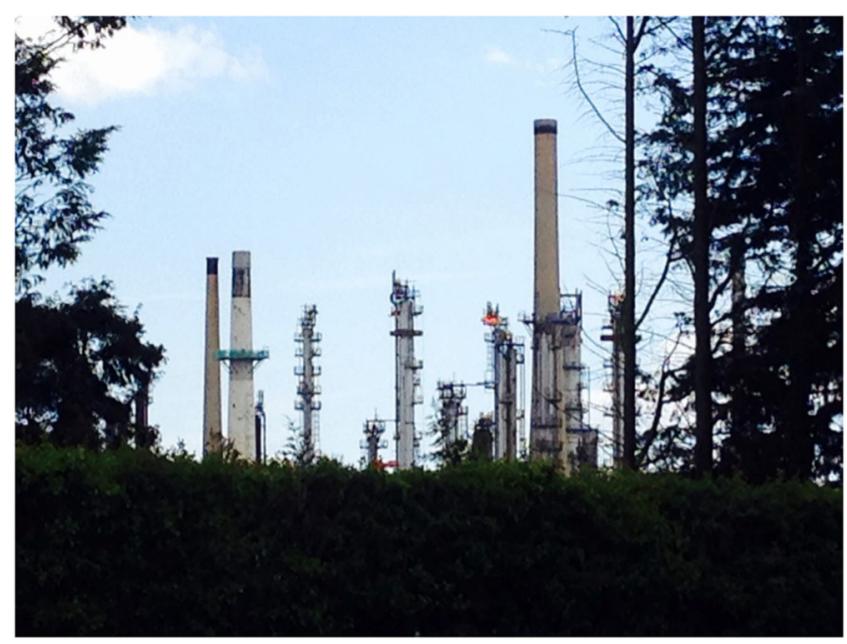

Figure I. Fawley ExxonMobil refinery and petrochemical plant, viewed from Long Lane, Holbury, April 2016.

has slowly fragmented. Yet by and large, Esso has managed to contain local discontent, adapting its strategies of community public relations to address controversies, and invoking its historical, trusted role in the community. While there have been many local complaints about air quality, oil spills, and other incidents, there have been no sustained environmental protests around the site, relatively few public controversies or significant media attention, ${ }^{1}$ and many local residents continue to place trust in the industry, while aware of the many incidents and risks. The case of Fawley complicates the understandings of the relationship between trust and risk, where public trust in a polluting corporation has endured on a general level, despite the cracks, yet public concerns and awareness of risks have also gathered pace, in bursts rather than continuously.

We begin this article by critically reviewing key social scientific debates on trust and risk, engaging with literatures on risk perception and the lived experiences of pollution. Next, we outline the case of Fawley, including the history of the site and the profile of the surrounding communities, before explaining our methodology. We then present our research findings, where we argue that enduring trust in industry has been maintained through careful reckoning with local risk over time, drawing from the residents' shared industrial heritage and enduring perceptions of Esso as a 'good neighbour'. This contrasts with expectations that there would be greater concern over risks and pollution in the present day as compared with decades ago, given the rising public awareness about environmental issues, with heightened environmental concerns today relating to a range of overlapping, multiscalar issues, notably climate change, air quality and plastic pollution. Yet despite continuities in risk and trust perspectives, our research also suggests that this balance of trust and risk could reach a breaking point if local grievances over lack of political participation and recognition remain unaddressed. Finally, we conclude by discussing the wider significance of our findings for understanding the dynamics of risk and trust in polluted communities.

\section{Social trust and risk perceptions in fenceline communities}

Environmental justice scholars have highlighted the highly unequal patterns of toxic pollution and contamination, with communities living in close proximity to polluting industrial facilities - areas 
referred to as 'fenceline communities' - at most risk of harmful exposures (e.g. Johnston and Cushing, 2020; Lerner, 2010). At the same time, an extensive body of qualitative risk perception literature has accrued on the local experiences and perceptions of risk sites in relation to the petrochemical industry (Burningham and Thrush, 2004; Bush et al., 2001; Phillimore and Bell, 2005), mining operations (Kojola, 2020), fracking developments (Eaton and Kinchy, 2016) and the nuclear sector (Parkhill et al., 2009; Zonabend, 1993). Many scholars have highlighted that the risk perceptions of local environmental and technological hazards are shaped by specific sociopolitical, economic and cultural contexts and are inextricable from wider perceptions of lived environments (e.g. Bickerstaff and Walker, 2003; Irwin et al., 1999). Others have highlighted the importance of capturing the everyday, embodied experiences of environmental degradation (Auyero and Swistun, 2009; Davies, 2018; Milbourne and Mason, 2017), particularly for communities which have observed toxic contamination as a form of 'slow violence' (Nixon, 2011) rather than major industrial disasters or controversies.

The importance of social trust is a key theme within the risk perception literature (Phillimore and Bell, 2005; Szerszynski, 1999; Wynne, 1992). As information on local environmental and health risks may be difficult to access and interpret, institutional trust in corporations and regulatory bodies to protect them from possible harm plays a central role in determining risk perceptions in fenceline communities (Shriver et al., 2014). In socio-cultural analyses of risk, trust is understood not as attitudinal nor as intrinsic to social actors, but as a fundamentally relational concept or, as Wynne (1992: 282) puts it, ' ... not trust and credibility per se, but the social relationships, networks and identities from which these are derived'. Typically, research suggests that social trust in industry is associated with a lower sense of risk in fenceline communities (e.g. López-Navarro et al., 2013; Mayer, 2016; Phillimore and Bell, 2005).

However, some authors have highlighted more complicated associations between risk and trust. Refining Giddens' (1990) and Beck's (1992) interpretation of reflexive modernity, Wynne (1992) suggested that public trust could be entangled with a fatalistic dependency on institutions and relative powerlessness. Drawing out the ambivalences of trust relations and lay assessments of risk, Wynne proposed that public displays of confidence can coexist with private mistrust in communities facing environmental hazards. Relatedly, Szerszynski (1999) built on Wynne's work through speech-act theory to highlight that declarations of public trust can sometimes be performative on the part of the community, in seeking to bind the industry into fulfilling its social obligations, even if ultimately futile. Our analysis extends this work, by resisting simple associations between trust and risk.

In fenceline communities that are economically dependent on industry, ambivalent attitudes towards risk and trust are common (e.g. Jovanović, 2018; Mah and Wang, 2019; Phillimore and Bell, 2005). There is evidence that local support for polluting industry is driven by socio-economic benefits, particularly in areas with few other employment opportunities (Boudet et al., 2016), leading to risk acceptance in many cases (e.g. Verbeek, 2020). Any criticisms of industry may be considered as self-defeating in contexts in which close socio-economic ties exist between community and industry, reflecting the 'jobs-versus-environment dilemma' (Räthzel and Uzzell, 2011). In the case of the Antwerp petrochemical complex, Verbeek (2020) found that risk acceptance was underpinned by the perceived community-level socio-economic benefits of the industry in terms of employment opportunities and local investment.

Perceptions of industry go beyond economic relations, however, in places 'whose way of life, its rhythm and pace, collective memories, and shared sense of identity bear the self-serving imprint of the dominant employer in the community' (McAdam and Boudet, 2012: 203). There has been growing research interest in the key role of cultural frameworks and place-based identities in shaping community responses to environmental threats, perceptions of industry, and local environmental conflicts (Adams et al., 2020; Lewin, 2019; Messer et al., 2015). The cultural dimensions of 
industry-community relations are foregrounded in cases where support for industry and risk acceptance continues despite the declining local economic and employment benefits (e.g. Bell, 2016).

For example, in a rural mining community in Northern Minnesota, Kojola (2020) found that support for a contested development was based on residents' emotional meanings of place and cultural heritage, not simply perceived material benefits. Moreover, in the petrochemical company town of Ludwigshafen (Germany), a remarkably close relationship formed between the community and BASF in the post-war period, with profound confidence in industry facilitating public disengagement on issues of environmental pollution (Phillimore and Bell, 2005). As Schlüter et al. (2004) argue, the community perceptions of polluting industries differ significantly between longestablished companies and new arrivals.

Many environmental justice scholars have drawn attention to cases of polluted communities where researchers would expect local mobilisations to occur over issues of environmental injustice, yet for various reasons, these struggles have not occurred (e.g. Gramaglia 2014; Mah and Wang, 2019; Neumann, 2016). Non-mobilisation tends to be more common than collective action in fenceline communities, with research pointing to the prevalence of 'inverse nimbyism' dynamics and local support for industry (Gravelle and Lachapelle, 2015; McAdam and Boudet, 2012). Sociological research has explored the reasons why local populations have remained quiescent in the face of persistent environmental degradation, toxic contamination and risky labour conditions (e.g. Adams et al., 2020; Bell, 2016; Lora-Wainwright, 2021; Shriver et al., 2014).

Explanations for non-mobilisation given include economic dependency, political allegiances and ideologies (Jerolmack and Walker, 2018), uncertainty around the sources and impacts of pollution (Auyero and Swistun, 2009; Shriver et al., 2020), the strength of collective and place-based identities (Lewin, 2019), and the powerlessness of local residents to voice and address grievances (Bell, 2016; Gaventa, 1982). Another common explanation for a lack of political mobilisation in fenceline communities is the normalisation of environmental and health risks. Corresponding with Giddens's (1990) theoretical construct of 'pragmatic acceptance', communities may resign themselves to living alongside toxic pollution and contamination. Similarly, much risk perception research has demonstrated the pragmatic and emotional coping strategies of risk communities (e.g. Atari et al., 2011; Zonabend, 1993). Local risk can be denied, suppressed or geographically and socially 'distanced' by residents, perhaps ' ... as an attempt to preserve their ontological security' (Luginaah et al., 2002: 185).

However, the public mood and risk perceptions can transform as industry declines, as highlighted in a number of sociological case studies (e.g. Irwin, et al., 1999; Phillimore et al., 2007). With the rise in automation and sub-contracting practices in refineries and petrochemical plants (Huber, 2013), the post-war social contract between industry and community has been increasingly eroded in the new flexible economy. Many communities living with industrial pollution have faced job losses and industrial decline, yet they continue to bear the toxic burdens of industry. For instance, Bush et al. (2001: 48) argued that the post-industrial Teesside environment was marked 'by the double insecurity of economic decline and environmental pollution'.

Schlüter et al. (2004) describe how the turnaround in the economic fortunes of the town of Grangemouth, Scotland, led to a reassessment of the balance of benefits and burdens of the proximal vast petrochemical complex in the local community. Reflecting the tensions and contradictions of living through socio-economic disruption, Mah (2012) suggests that an 'ambivalent nostalgia' can form among older residents of deindustrialised communities, where they yearn for the economic vitality of former times while also recalling the toxic pollution. Mah argues that industrial ruination is a protracted, ongoing process rather than a distinct event, while Linkon's (2018) concept of the 'half-life of deindustrialisation' captures the extended, persistent and intergenerational effects of industrial decline on local attitudes and culture years after the closure of factories. 
Trust in both corporations and regulatory authorities tends to be dented by declining economic security or increasing signs of environmental degradation, associated with feelings of unease, frustration and anxiety among residents (Atari et al., 2011). In Ludwigshafen, Phillimore and Bell (2005) uncovered growing limits to trust, primarily driven by increasing outsourcing and subcontracting of employment at the site, and revealed underlying doubts and uncertainties beneath the surface of public confidence. Their findings point to contingent, fragile trust in cases of risk acceptance in polluted industrial communities. As research in other contexts has similarly revealed (Parkhill et al., 2009; Simmons and Walker, 1999; Zonabend, 1993), public trust can exist in tension with subdued, latent anxieties in fenceline communities. The decline of trust in polluted fenceline communities connects to environmental justice scholarship about the role of recognition and political participation (e.g. Coolsaet and Neron, 2020; Schlosberg, 2007). Our research contributes to these debates, highlighting the importance of recognition of local people's perspectives in the endurance of trust relations in Fawley.

\section{Case study and methodology}

\section{The case: Fawley refinery and petrochemical complex}

Covering 3250 acres and bounded to the East by mudflats, saltmarsh and Southampton Water, the Fawley refinery complex comprises the Esso oil refinery, the ExxonMobil petrochemical plant and the Nalco Manufacturing Ltd chemical plant (ExxonMobil, 2018). To the North is the Charleston Road Industrial Estate where, from the 1950s, related industries established themselves. While companies have moved in and out over the years, as of 2020, the industrial estate incorporates gas and fuel suppliers (Calor Gas, Flogas Fawley, BOC Gases Ltd and WP Group), a chemical and plastic manufacturer (Geo Speciality Chemicals), a power generation site (RWE Cogen Ltd) and a hazardous waste treatment and disposal centre (Tradebe Fawley Ltd). Additionally, a now decommissioned gas-fired power station lies to the south of Fawley.

A refinery was originally established on the site in 1921 by the Atlantic Gulf and West Indies (AGWI) Petroleum Company, later acquired by Esso in 1925 (Esso UK Limited, 2011). As a part of Britain's post-war recovery programme, the Fawley refinery was rebuilt and substantially expanded, to increase the country's refining capacity and reduce its dependency on the import of refined oil from the US (Sheail, 2002; Walker et al., 1998). The refinery officially reopened in September 1951 and in subsequent years expanded its capacity and range of processes and products, with additional units and plants constructed from the 1960s to the 1980s, notably the integrated expansion of petrochemicals manufacturing at the site (Esso UK Ltd, 2011). Alongside the production of petrol, diesel, fuel oil, kerosene and jet fuel, the refinery also generates feedstock for use in the integrated ExxonMobil chemical plant, responsible for approximately 850,000 tonnes of petrochemical products per year (ExxonMobil, 2019). It continues to be invested in, with the New Forest District Council (NFDC) approving ExxonMobil's plans for the expansion of the refinery in 2019 including the installation of a hydrogen plant and a hydrotreater unit, purportedly enabling the production of ultra-low sulphur diesel at the site to increase by around $45 \%$ at a cost of over $£ 800$ million. Despite its strategic importance as a major European site of oil and petrochemical production, the Fawley site has not been widely studied.

The communities surrounding the refinery site include the villages of Fawley, Holbury, Hardley, Blackfield and Langley to the South and West of the site and the town of Hythe and the village of Dibden to the North (see Figure 2 below). Along with Marchwood, this area is collectively known as Waterside. Some of the closest properties in Fawley and in Hardley are approximately $100 \mathrm{~m}$ away from the refinery site (NFDC, 2008). The residential neighbourhoods in Waterside area developed closely around the Esso refinery, underpinning the area's rapid growth and prosperity from the 
1950s. While Waterside communities were previously sparsely populated agricultural settlements, the population of Fawley Parish doubled in size between 1951 and 1981 (Walker et al., 1998).

At its peak in the 1970s, over 3000 people were employed at the refinery site (Walker et al., 1998), with most residing locally, including in small housing estates built by Esso for its workers. Although the refinery remains the largest heavy industrial employer in Hampshire (NFDC, 2019), organisational changes since the 1990s have led to a reduction in the size of the refinery workforce. Today, around 1500 people work at the refinery complex, fluctuating in and out of shutdown periods, with many of these engaged on a temporary and sub-contracting basis (Interview, May 2020). Significantly fewer of Esso's employees reside locally compared to the post-war period. Data from the 1971 census reveal that approximately $42.3 \%$ of the economically active population in Fawley Parish worked in the manufacturing industry, the majority of whom were employed locally, compared with only $12.6 \%$ in the most recent census in 2011 (Office for National Statistics (ONS), 2011).

Socio-economically, in contrast with many petrochemical fenceline communities around the world (Davies, 2018; Jephcote and Mah, 2019; Mah and Wang, 2019), much of Waterside is reasonably affluent, as is the case across the New Forest district more broadly (NFDC, 2009). However, there are pockets of social deprivation in Waterside, including the wards of Dibden and Blackfield, which are among the 10\% most deprived areas in England, with particular problems related to poor transport connectivity to access jobs and services, and low levels of education, qualifications and training (Hampshire County Council, 2021). The Waterside area today functions largely as a commuter zone for nearby Southampton and as a retirement belt, made up of a large number of former Esso employees. Fawley Parish contains a relatively high number of retired citizens (19.1\% compared to $16.4 \%$ for the UK as a whole) (ONS, 2011), reflective of an ageing population more broadly in the New Forest District (NFDC, 2018).

\section{Methods}

This paper compares the local risk perceptions of Fawley residents across two qualitative studies: one in 1997 and one in 2019. While having distinct research aims, purposes and designs, the studies

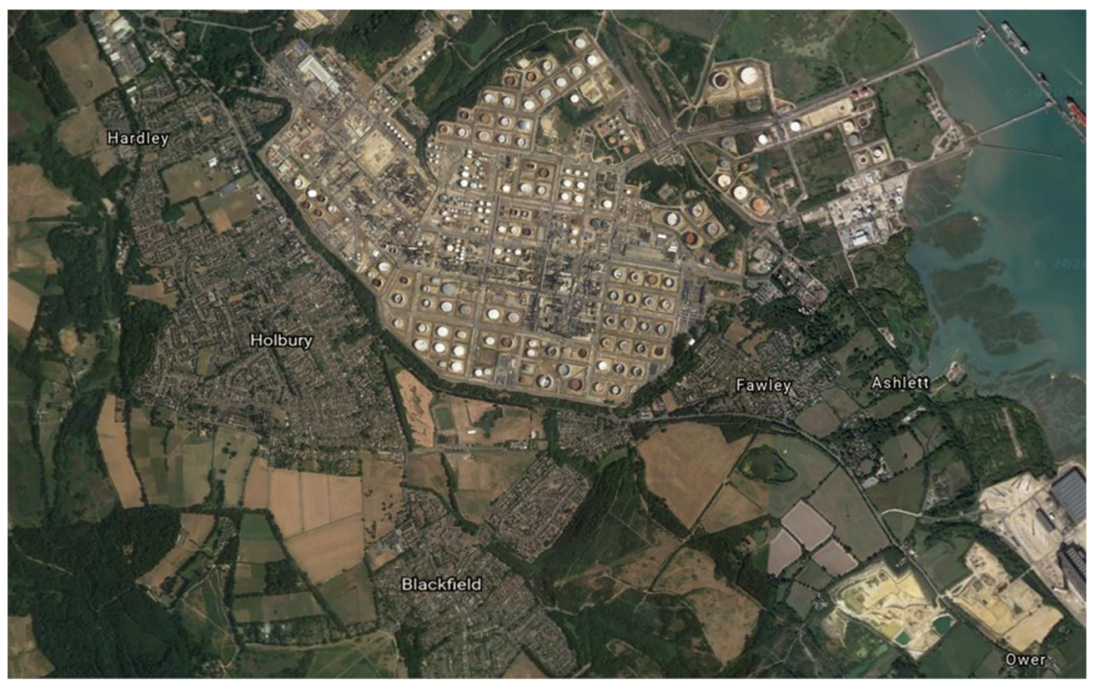

Figure 2. Aerial map of Waterside area (Ordinance Survey Maps, 2021). 
both explored local perspectives on the refinery industry and related risk. By examining the Fawley case at two points in time, we are able to reveal the temporal dynamics of trust relations and risk perceptions in a specific fenceline community context. Across the two datasets, we draw out common and divergent themes, discourses and concerns of the communities living alongside the Fawley refinery. Accordingly, we put forward a novel methodological basis for the exploration of risk and trust, one which is distinctive from the majority of studies of risk perceptions or industrial polluted communities that are anchored to one point in time.

While the 1997 research findings formed a part of a multi-case study report on communities living alongside major hazard sites in the UK for advising the UK Health and Safety Executive the 2019 data were collected to examine risk perceptions in Fawley as a case study of the petrochemical industry. In the 1997 research, eight focus groups were held with local residents, with the first of two meetings with each group centering on the local setting, local risks and views on Esso and its impacts. The second round of meetings involved deliberations on land use planning scenarios and were not drawn on for this paper. The research design of the 2019 study in Fawley was inspired by the 1997 study but did not seek to replicate it. It followed pilot research in Fawley including a community tour of the refinery in 2016 and attendance at Environmental Protection Liaison Committee meetings at the NFDC offices in Lyndhurst between 2017 and 2019. In July 2019, two focus groups were carried out with local residents in Fawley and Hythe, lasting around two hours each, in addition to nine semi-structured interviews with residents.

Focus groups can reveal more dynamics than a one-to-one interview and the ways in which participant's viewpoints are generated, expressed and challenged (Bedford and Burgess, 2001; Longhurst, 2003). Notably, they allowed for an exploration of the relative stability and robustness of local views on risk (Walker et al., 1998). In the 2019 study, individual interviews were offered to those who could not attend the focus groups or as an alternative option for those who preferred a one-to-one discussion, adding supplementary richness to the data, building on and complementing the focus groups. Given that the use of focus groups in a 'company town' setting with a dominant industry identity may lead to consensual opinions being formed (see Bell, 2016), the use of individual interviews and informal discussions sought to facilitate the revealing of perspectives on local risk which may be otherwise concealed in a group setting.

While guided, focus group discussions were generally open and loosely structured. Broadly similar themes and research enquiries were explored in 1997 and 2019, where participants were asked about their perceptions of environmental and health impacts of the refinery, Esso's role in the community and wider views about the local area, drawing from their retrospective narratives and ongoing experiences of living alongside the refinery. However, while the 2019 fieldwork focused more directly on perceptions of industry and risk, the 1997 study also investigated local understandings of regulations of industrial hazards, planning scenarios and deliberations among participants over how to best respond to these hazards. Distinct discussion guides and interview questions were used in each study, with the 2019 guide adapted to the contemporary context, taking into account, for instance, recent local incidents and environmental regulations.

In the 1997 focus groups, recruitment was structured (using a professional agency) to include a range of age, gender class and employment profiles, with two groups made up of current and former Esso employees. Meanwhile, the 2019 participants were recruited using convenience sampling through promoting the focus group events in a range of places: leafleting at relevant community hubs (e.g. libraries and community centres), local newspapers and community groups on social media. The majority of participants in the 2019 focus groups and one-to-one interviews were over 50 years old, and included a range of men and women who lived in the area, both Esso employees and ex-employees, or people with family members who worked at the refinery, as well as relative newcomers to the area. The participant selection in the focus groups reflected the ageing demographics of the area and those with the free time to attend such events, but also, given the 
focus of the research, those who were most interested in conversing over the historical role and impacts of the refinery in the local area. This resulted in a bias in the sampling towards the older generation and those with closer, more personal attachments to Esso, which, we acknowledge, may have impacted on the comparative findings.

In both 1997 and 2019, to gain an enhanced understanding of the local socio-economic, cultural and environmental context, relevant local stakeholders were interviewed, including representatives from the NFDC, Fawley Parish Council and the Environment Agency, a Unite the Union representative from the refinery and members of regional environmental campaign groups. All the research was carried out in line with ethical commitments to informed consent, anonymity and confidentiality. Local information sources were also drawn upon in this research, primarily Esso's corporate documents, webpages and the 'Community Matters' magazines that are regularly distributed to local residents, relevant reports from the NFDC, documented minutes from the quarterly Environmental Protection Liaison Committee meetings and local news articles. Additionally, data from the census (both historical and recent) and the multiple index of deprivation was used to contextualise the analysis.

For this comparative research, the textual data from the two studies - the focus group and interview transcripts and relevant documents - were analysed using a thematic coding process through the qualitative data analysis software NVivo. Codes and themes emerged inductively from the textual data, but they were also developed and critically interpreted in relation to wider theoretical frameworks of risk perception and relevant prior research. As a part of an iterative process, the data were frequently revisited and re-examined in light of wider theory and other findings, including contextual data. Residents' responses were corroborated with other accounts and contextual data, aligning with the approaches of other studies of fenceline communities (e.g. Adams et al., 2018).

\section{The tenacity of trust in Fawley}

In both of our Fawley community studies, our findings indicated relatively high levels of social trust in Esso, but also relatively high levels of risk perception. The 1997 research identified a collective sense of trust in Esso in Fawley, distinct from the other hazard sites that were a part of the larger comparative study, balancing out the pervasive worries and elements of distrust. In 2019, local residents continued to place cautious trust in Esso as an industrial neighbour, which capitalised on its long-standing role in the community. In this analysis, we argue that the tenacity of trust in Fawley is based on a delicate balance of heritage, risk and recognition.

First, the shared industrial heritage of Waterside residents accounts for their enduring trust in Esso, despite the sense of decline. Second, we highlight ambivalent reckonings with risk, where the environmental and health threats of the refinery are managed and navigated by residents over time, connected to a continued confidence in Esso to act, on the whole, as a responsible neighbour. Third, the company's historical and ongoing recognition of community concerns acts as a crucial driver for the maintenance of social trust in the industry. Over the next three sections, we discuss each of these elements in turn through an integrated, comparative analysis of qualitative data from 1997 and 2019.

\section{Shared industrial heritage}

Susan, a former Esso employee who has lived in Waterside all her life (individual interview, 2019), praised the company's safety and environmental record and sought to dispel myths that have developed in the local area. She drew a distinction between the experiential knowledge of the longstanding residents and what she saw as unfair misconceptions about Esso of more recent arrivals to the area, as described in the following: 
... a lot of people have an opinion of the refinery and they're not necessarily people who have been around very long or have lived in the area very long, or have even worked in the site or even set foot inside the site and so therefore, some of their opinions - and I suppose this has become more prevalent with social media... But they've developed into like these urban myths and you know, that people believe and also a lot of strange things about the refinery. You know, it's not my job to put them right on it, you know?

Here, Susan's trust in Esso was expressed through a staunch defence of the company in response to perceptibly damaging criticisms. Susan's comments capture the tensions that exist in Waterside communities between the older generation that hold long-standing connections with Esso and the newer residents, attracted to move to the area by its close proximity to the New Forest national park. Similar tensions were evident in some of the 1997 group discussions, although newer residents without connections to Esso were less numerous at that time.

Enduring trust in Esso is partly accounted for by a shared industrial heritage, closely connected to the post-war social contract that built up between the company and the surrounding communities. In both studies, older residents who had grown up in Fawley tended to highlight the economic benefits that Esso had brought to the area, notably the employment of local people with good salaries and substantial benefits (e.g. pensions), the public services funded by high business rates generated from the refinery, the Esso social clubs at Holbury and Ashlett Creek, and 'Essoville', the subsidised housing scheme for refinery employees. Many of the residents also defended Esso against the criticisms it has faced over environmental impacts in recent years, often remarking that newcomers to the area complained without having grown up around the refinery or having witnessed the air quality improvements since the 1970s. The residents also raised questions over why newcomers had moved to the area if they knew of the close proximity of the refinery.

While the criticisms of Esso were more likely to be voiced by newer residents, many longstanding residents also lamented the decline of community-industry relations, evaluating Esso's current contributions to the community against its greater social provisions of the post-war years. Having grown up with a close-knit community centred around multi-generational work at the refinery, these residents expressed some disillusionment at a loss of community cohesion in Waterside. Across both studies, participants commented on the declining socio-economic benefits of the refinery for the local population and the shifting identity of the area, away from being an industrial hub towards becoming a green commuter belt and a retirement belt, a process that was already well underway by 1997 . Esso was perceived to have 'socially retreated' from the surrounding neighbourhoods (2019 focus group discussion), exemplified by the closure of the social clubs, while also framed on occasions as being less caring and community-minded than it once was, for example, by failing to provide adequate health and safety training for workers or infrastructural upgrades.

However, when concerns over Esso's operations were raised in focus group discussions, residents often qualified or downplayed these, returning to the theme of positive contributions that the company has made in the local area. Residents also argued that Esso had good intentions and that company representatives were 'not happy' and 'apologetic' when there were excess emission releases from the site (2019 focus group discussion). Newer residents did not seek to mobilise against the industry, as has been found in other cases (e.g. Kojola, 2020), but instead their responses tended to echo local structures of feeling around Esso and its contribution to Waterside. The lack of activism on the part of newcomers could also be explained by the role of private property values in residents downplaying environmental problems (see Pitkanen, 2017). The sharpest criticisms of Esso were marginal in the local population, with many calls for the firm to reduce levels of noise or flaring, rather than anything more fundamental: in essence, to function as a 'good neighbour'. 
With a mythology having formed around the post-war period, as an industrial 'golden age', the older generation in both studies recalled the coming together of workers and their families from different parts of the UK to build and work in the refinery in its early days, echoing the sense of pride felt in Ludwigshafen in 'being associated with something gigantic and pioneering' (Phillimore and Bell, 2005: 327). These residents reminisced over growing up as a part of a close-knit industrial community, particularly the social life connected to Esso, of having taken the well-trodden path from school to apprenticeships at the refinery, and of hard work at the refinery that was amply rewarded by Esso. Many began conversations by announcing that they or family members had worked at the refinery for a lengthy number of years. The persistence of these narratives in both 1997 and 2019 points to the longevity of collective memory and attachment in communities that have developed closely around a particular industry.

On many occasions in both studies, local residents placed emphasis on being close to nature, alongside the New Forest, an area of natural beauty, and the coastal environment, sometimes as ways of diverting attention away from the negative environmental impacts of the refinery. Their sense of place relates to both work at the Esso refinery and to recreational activities in the surrounding national park. While in other contexts the two may be in conflict with each other (e.g. Kojola, 2020), local industry and natural landscapes were both drawn upon in the collective memories and personal stories of older Fawley inhabitants, suggesting a co-existing shared heritage for these residents. The Waterside area was also framed as being cleaner and greener than polluted urban centres, enabling local discourses of green landscapes and clean air, on the one hand, and a prosperous yet polluting refinery industry, on the other hand, to simultaneously dominate.

Since the mid-1990s, Esso has sought to actively maintain and amplify the shared industrial heritage of the Waterside communities. Through a local public relations campaign, via corporate communication on their webpage, the 'Community Matters' magazine distributed locally, and at community events, the company presents itself as the backbone of the local economy, an important, enduring element of local community life and as a responsible neighbour, echoing the narratives deployed by polluting firms to placate surrounding community members elsewhere (e.g. Bell and York, 2010; Jobin, 2020). At the same time, the negative aspects of the company's history in the area, such as accidents, industrial pollution or labour struggles, are omitted from such corporate accounts.

Despite its declining social function over the years, Esso has remained present in numerous aspects of local public life, including sponsored events; uniformed employees assisting with community projects through the 'Volunteer Improvement Programme'; sponsored local infrastructure (e.g. seats, flowerbeds); and engagement with local schools through 'The ExxonMobil Link Schools programme'. As Bell and York (2010: 136) argue, these tactics provide an opportunity for the corporate logo to be widely present in the public domain and to "penetrate the lifeworld' of the community, thereby serving 'to perpetuate an ideology of dependency' on the company.

Overall, despite strands of distrust and disquiet among the local population, trust in Esso endured across 1997 and 2019, underpinned by the shared industrial heritage of the area and a lack of clear disjuncture with the past. Common perceptions of Esso built up in the post-war period, as a fair employer of local people and as a responsible neighbour, persisted among the older generation. The longevity and sheer familiarity of the Esso refinery has developed over decades in Fawley, evoking similarities with the unusual loyalty in industry uncovered in Ludwigshafen (Phillimore and Bell, 2005) and Antwerp (Verbeek, 2020). However, the shared heritage is not able to entirely contain risk in Fawley, with the residents found to carefully reckon with risk over time through active negotiations and assessments. 


\section{Ambivalent reckonings with risk}

Since 1951, the Fawley site has been the subject of periodic local controversies, connected to explosions, accidents, emissions, worker safety and noise pollution (see Table 1). Despite this, the majority of risk incidents were not considered to be threatening to the local population to the extent that they would seek to relocate due to health and environmental concerns or campaign against the industry in the way that other environmental justice movements across the world have done in response to toxic exposure (Bullard, 1990; Schlosberg, 2007). In general, most Fawley residents would not identify themselves as living in a contaminated or fenceline community.

As a result, direct opposition to the industry from local residents has been rare. While 120 formal objections were made to the NFDC in 2019 on the proposed refinery expansion, the majority of these originated from regional environmental groups external to the area, primarily on the basis of climate change concerns, such as the Southampton branch of Extinction Rebellion and New Forest Friends of the Earth. Risk concerns tend to be contained at the level of individual complaints in Fawley, with residents reporting noises, smells and flaring from the site, typically following particular incidents, directly to Esso or alternatively to the local authority or the Environment Agency. In 1997, the company stated that it sought to ensure that all complaints were 'investigated and dealt with promptly, sometimes by public relations personnel and at other times by technical staff, depending on the nature of the complaint' (Walker et al., 1998: 40). This tactic of dealing with local complaints remained intact in 2019.

In both studies, Fawley residents recognised, understood and recalled the environmental and health risks associated with local industry, rather than denying or suppressing these based on attachments to Esso. These risks encompassed the persistent threat of a large-scale accident, chronic air pollution, dust, strong odours, flaring and in 2019 noise pollution from the site, caused by leaks from a steam generation plant, as confirmed by the Environment Agency following an investigation (2019 interview with EA representative). However, these local risks were also justified, downplayed or normalised by residents, blending into everyday routines and familiar structures. Indeed, a 1997 participant commented, 'I just don't know any different, that's it, I just don't know any different'. Across both studies, participants even referred to the background noise from the site as 'soothing'. Fawley residents sought to take action within their control, such as closing windows and staying inside on days of high pollution, a common mitigation strategy in other polluted fenceline communities (Lora-Wainwright, 2021; Mah and Wang, 2019).

In 1997 and 2019, fears over the possibility of a major accident occurring at the site were heightened by the ageing refinery infrastructure - variably labelled as 'rusty', 'rotting' and 'falling apart' - and the perceived decline in health and safety proficiency of the Esso workforce, latterly supported by a Health and Safety Executive (HSE) investigation of the site (Law, 2008). However, the threat of a major accident at the refinery was often temporally distanced by residents, placed either in a bygone era or in a far-removed future. The older residents' recollections of notable incidents from the 1960s and 1970s - as distressing childhood memories - serve to situate the substantive threat of a large-scale accident in a seemingly distant past For example, Rosie, a 1997 participant, recounted an explosion that others in the group also recalled:

When I was a little girl they actually had an explosion and I mean, my dad was in there at the time and that was frightening, and I mean, if that didn't put me off, the whole house shook. The sky was blood red.

These acute risks from the refinery were understood to be much lower in recent times and, despite Esso's cost-cutting measures, there was a general feeling among participants that they are safer than in previous decades given the company's more stringent health and safety regulations. 
Table I. List of Fawley incidents and responses.

\begin{tabular}{|c|c|c|c|}
\hline Incident or issue & Date & Public response & Corporate response \\
\hline Powerformer fire & $\begin{array}{l}\text { 1969. Other smaller } \\
\text { fires occurred at } \\
\text { the powerformer in } \\
\text { 1962, 1965 and } \\
\text { earlier in } 1969 .\end{array}$ & $\begin{array}{l}\text { Alarm, increased sense of } \\
\text { risk. }\end{array}$ & $\begin{array}{l}\text { Improved safety procedures } \\
\text { and infrastructure from } \\
\text { the 1980s, in line with the } \\
\text { implementation of the } \\
\text { Seveso Directive (1982) } \\
\text { and the British Control } \\
\text { of Industrial Major } \\
\text { Accident Hazards (1984). }\end{array}$ \\
\hline $\begin{array}{l}\text { Airborne releases from } \\
\text { the refinery including } \\
\text { catalyst dust, black } \\
\text { soot, oil mist and } \\
\text { mercaptan. }\end{array}$ & 1993 & $\begin{array}{l}\text { A relatively high number of } \\
\text { local complaints against } \\
\text { Esso, particularly in } \\
\text { response to the } \\
\text { mercaptan release from } \\
\text { the chemical plant. } \\
\text { Complaints followed in } \\
1995 \text { after spikes in } \\
\text { sulphur dioxide releases. }\end{array}$ & $\begin{array}{l}\text { Investigation of complaints, } \\
\text { curbing of unplanned } \\
\text { releases. }\end{array}$ \\
\hline $\begin{array}{l}\text { Cat cracker fire/ } \\
\text { explosion }\end{array}$ & 1990s & $\begin{array}{l}\text { Alarm, increased sense of } \\
\text { risk }\end{array}$ & $\begin{array}{l}\text { Wake-up call, improved } \\
\text { infrastructure, drill } \\
\text { procedures, etc. }\end{array}$ \\
\hline $\begin{array}{l}\text { Regional TV } \\
\text { documentary linking } \\
\text { emissions from the } \\
\text { refinery with } \\
\text { localised health } \\
\text { problems, notably } \\
\text { asthma }\end{array}$ & 1994 & $\begin{array}{l}\text { Although a subsequent } \\
\text { health survey did not } \\
\text { verify these claims, } \\
\text { increased public } \\
\text { concerns around local } \\
\text { health in the subsequent } \\
\text { years. }\end{array}$ & Unknown \\
\hline $\begin{array}{l}\text { Air Quality } \\
\text { Management Area } \\
\text { (AQMA) }\end{array}$ & 2005 & $\begin{array}{l}\text { Local concerns around the } \\
\text { high levels of sulphur } \\
\text { dioxide emissions in } \\
2003 \text { and } 2005 \text {. } \\
\text { Subsequent monitoring } \\
\text { and regulations, revoking } \\
\text { of AQMA in } 2013 \text {. }\end{array}$ & $\begin{array}{l}\text { More communication with } \\
\text { council and community, } \\
\text { greater involvement with } \\
\text { the multi-stakeholder } \\
\text { environmental liaison } \\
\text { committee }\end{array}$ \\
\hline $\begin{array}{l}\text { Health and Safety } \\
\text { Executive Report: } \\
\text { Workers safety fears }\end{array}$ & 2008 & $\begin{array}{l}\text { Media exposure; workers' } \\
\text { safety fears }\end{array}$ & $\begin{array}{l}\text { Denial of these claims in the } \\
\text { official statement } \\
\text { released by ExxonMobil. }\end{array}$ \\
\hline Noise complaints & 2019 & $\begin{array}{l}\text { Media exposure; specific } \\
\text { residents and } \\
\text { community (Holbury) } \\
\text { affected }\end{array}$ & $\begin{array}{l}\text { Started to take noise } \\
\text { complaints more } \\
\text { seriously, investigated } \\
\text { source, damage control }\end{array}$ \\
\hline $\begin{array}{l}\text { Climate concerns re: } \\
\text { plant expansion }\end{array}$ & 2019 & $\begin{array}{l}\text { I20 formal objectives to } \\
\text { Esso's proposed } \\
\text { expansion of diesel } \\
\text { production at Fawley } \\
\text { refinery received by the } \\
\text { NFDC, primarily from } \\
\text { regional environmental }\end{array}$ & $\begin{array}{l}\text { With concerns largely being } \\
\text { non-local, aggressively } \\
\text { defend themselves } \\
\text { against climate change } \\
\text { objections. Justify the } \\
\text { expansion of ultra-low } \\
\text { sulphur diesel on the }\end{array}$ \\
\hline
\end{tabular}


Table I. Continued

\begin{tabular}{|c|c|c|c|}
\hline Incident or issue & Date & Public response & Corporate response \\
\hline & & $\begin{array}{l}\text { groups and NGOs } \\
\text { outside of the local area, } \\
\text { for example, New } \\
\text { Forest Friends of the } \\
\text { Earth, Save Our Shores } \\
\text { (SOS), Extinction } \\
\text { Rebellion Southampton, } \\
\text { links to heightening } \\
\text { global concern over } \\
\text { climate change, } \\
\text { particularly related to } \\
\text { 'climate emergency' } \\
\text { awareness. }\end{array}$ & $\begin{array}{l}\text { basis that it will reduce } \\
\text { imports of diesel and that } \\
\text { it will be better for the } \\
\text { climate than more } \\
\text { harmful imported diesel } \\
\text { from elsewhere; } \\
\text { 'shut-down' is a } \\
\text { non-starter, although on } \\
\text { a global level the } \\
\text { company is under } \\
\text { increasing pressure }\end{array}$ \\
\hline
\end{tabular}

One 1997 participant stated that 'I believe Esso itself have a very high safety standard and they do know what they're doing and they have got their regulators in there, the safety people in there ... '.

Public concern over air quality in Waterside became prominent with the high levels of sulphur dioxide $\left(\mathrm{SO}_{2}\right)$ emissions in the early 2000s and the subsequent declaration of the Air Quality Management Area (AQMA) in Fawley by the NFDC in 2005, following the exceedance of the 15-min mean objective for $\mathrm{SO}_{2}$. The NFDC (2008) concluded that the majority of $\mathrm{SO}_{2}$ emissions in this period originated from the Esso refinery, although noted the 'unusual weather conditions of strong north westerly winds' observed in 2005. Following the AQMA declaration, Esso worked closely with the NFDC to re-establish trust with the local community, notably through attendance at Environmental Protection Liaison Committee meetings, but also through informal channels as a part of a more open communication strategy with local authorities, as remarked by a NFDC interviewee (2019 interview):

... And I think that's why it's improved us working together. Now I'd phone up and say, you know, 'Well what have you just done?' You know, we've got that kind of relationship and a bit of a relaxed relationship so....

While certain incidents, such as flaring or notable noise disturbances, may necessitate Esso being brought into line (e.g. through fines), the findings largely indicate a broad toleration by the NFDC of industry transgressions within certain boundaries. The NFDC has acted as an intermediary and negotiator of sorts between Waterside residents and industry, thereby reassuring the local community over air quality issues, notably through the successful enforcement of the AQMA, documented improvements in Fawley air quality since 2005 (NFDC, 2018), and continued air quality monitoring after the revoking of the AQMA in 2013. While many older residents across both studies acknowledged that local air quality has improved in recent years, they also expressed concerns over what they have been 'breathing in' over the years and the lasting toll that prior decades of toxic air pollution may have left on their bodies, notably the high levels of $\mathrm{SO}_{2}$ emissions experienced between the 1950s and the 1970s, referred to locally as 'yellow fallout'.

In both 1997 and 2019, some residents recalled lived health experiences of local pollution, including feeling breathless on days of high pollution, nauseous from distinct odours or having sleep disturbed by noise pollution. The distinctiveness of health conditions in Waterside was 
recognised by many residents, referring to perceptibly high levels of asthma, hay fever, stunted growth and various forms of cancer among family members and neighbours, which have developed into normalised features of the local area. However, with the exceptions of the occupational diseases of mesothelioma and asbestosis, residents were reticent to make direct connections between the refinery operations and local health conditions. There were no official epidemiological studies which they could draw from, although a 1994 TV documentary provided some weight to concerns around local asthma prevalence in the 1997 focus groups. While indicating profound uncertainties and doubts over the possible impacts of toxic exposure from the refinery on their longterm health (e.g. 'it makes you wonder'; 'who knows?'), residents also largely downplayed and qualified the possible impact that Esso's operations may have had upon the health of the local population in a context of multi-point industrial pollution.

For example, Margaret, one older resident in 2019 (focus group discussion), made a significant lay claim on the prevalence of cancer in the local area, reflecting that all the deaths that had occurred on her road that she could think of were attributed to cancer. However, she quickly qualified these claims by highlighting that 'cancer is everywhere now' and that the number of cancer-related deaths on her street is not significant over her 'whole lifetime', while subsequently pivoting to emphasise the local socio-economic benefits that Esso had provided. Similarly, a 1997 participant indicated a conflicting narrative of local risk in describing their experience of visiting nearby beaches:

In the summer... you can go down to Calshot or Lepe and end up covered in oil ... I'm sure it's happened to other people. I hate that, you know, because you can go to other beaches at Bournemouth and you don't have to worry about it. I don't know about the water itself ... I don't think that's as polluted as it might appear to be, because it does look quite murky and dirty....

The resident pointed to dangers and anxieties around oil pollution in the local environment, but simultaneously downplayed the severity of the pollution, reflecting the broader ambivalent attitudes towards risk in Waterside. The findings from both 1997 and 2019 indicated a careful reckoning with local risks that residents have learnt to live with and navigate over time. Everyday environmental and health threats from the refinery were managed and navigated via processes of normalisation and relativisation, strategies of temporal and spatial distancing and an enduring confidence in Esso to act, on the whole, as a responsible neighbour. Recognition is also a key factor through which local residents reckon with risk.

\section{Recognition}

The ability to voice critical concerns around refinery operations and to be reciprocated in some form by Esso has been important in maintaining trust relations with the company and containing local risk. In 1997 and 2019, older residents recalled Esso's long history of reciprocity and contribution to the community, notably the compensation that could be claimed from Esso for particular issues, either historically or ongoing in the present. For instance, in a 2019 focus group discussion, two long-standing residents, Margaret and Janet, drew out detailed collective knowledge of Esso's compensatory mechanisms in response to specific industry-attributed illnesses, notably asbestosis:

R1: Yes, asbestos - they still pay out on asbestos.

R2: Oh do they? So you know of people?

R1: Yes, I know of people that have been paid out because their husband's died...and where the wife was doing the washing. You know, they have to compensate for the asbestos. 


\section{R2: So it's been down as being from Esso? \\ R1: Yes, oh yes and they will pay out on that.}

Among the older generation, fears around latent and ongoing illnesses attributed to industry, such as asbestosis, as well as accidents that occurred at the refinery site, are offset to some extent by the compensation offered by Esso, as indicated by Janet when recalling a friend's experience at the refinery:

... her father got badly burnt in one of the bad fires, but the compensation - not that it matters, but it was really good. You know, it doesn't matter because he was quite badly burnt, but at least they looked after him and that's what it's about, isn't it, looking after people?

While acknowledging local risks, there is a sense in which residents feel that they have voice and recognition, evidenced through the detailed knowledge of knowing who to complain to and what kinds of compensation are available. Moreover, it was well-established in the 1997 and 2019 discussions that, following complaints over black soot deposited on cars, windows or laundry, Esso had historically sent out its employees to help with the clean-up of these, or in some cases, grant compensation. We found that Esso's recognition of compensatory claims and active community assistance in Fawley has played a key role in maintaining its enduring positive image among the local population and has facilitated continued confidence that the company will appropriately manage risk associated with refinery operations.

Compensation payments, alongside the 'good neighbour' public relations strategies and diverse forms of corporate patronage described earlier, form a part of what Jobin (2020) refers to as 'fuel money', tending to legitimise pollution and shape community grievances. However, the findings suggest that flows of money from Esso do not mean that chronic pollution, latent health impacts and the ever-present threat of industrial accidents are accepted by local residents. We suggest limitations on the extent to which these corporate tactics can effectively contain risk, with the findings indicating widespread uncertainties and fears around health, particularly for those conditions that have not been clearly attributed to industrial pollution and for which there is no compensation (e.g. cancers and respiratory issues), indicative of the unevenness and inadequacy of corporate pay-outs described elsewhere (Jobin, 2020; Mah and Wang, 2019).

Since the mid-1990s, Esso has moved towards opening up lines of communication with the surrounding residents through, for instance, organisation of community tours of the refinery site, distribution of the 'Community Matters' newsletter and involvement in the New Forest Environmental Protection Liaison Committee meetings. Notably, the company has established formal complaints mechanisms, whereby residents can call Esso operatives to voice concerns over distinct odours, noises, dust or smoke in the area. Many long-standing residents pointed to the ability to directly and immediately highlight issues to Esso as a key element of the enduring trustworthiness and community-minded nature of the company. For example, one older resident (individual interview in 2019), reflected, ' ... I always say to people, "Just phone them up and ask and if the security on the phone knows then they will tell you". And if not, they will try to find out ... just in case it is them'. The comment signifies a persistent confidence in Esso to protect the local community and assumes a high degree of integrity and honesty on the part of the company.

The most profound grievances indicated in 2019 were around the prominent issue of noise pollution. The Environment Agency recorded spikes in noise-related complaints from the area in April and June 2019 (2019 interview with EA representative). Acute frustrations emerged among the local population in response to the perceived inadequate public engagement by Esso on the elevated levels of noise pollution. In particular, a couple residing in Holbury (2019 focus group participants) 
suffering from noise pollution had begun by initially complaining to Esso through the hotline, but expressed frustrations at the way that they had been treated by the company:

You don't get treated very well, out of hours. They laugh at you, the lads. 'We can't hear anything, you're the only one who's phoned up'.

Esso is very apathetic towards you, I suppose is the right word. They don't really want to know...

These residents felt that they had been ridiculed and not taken seriously by Esso over their concerns which, for them, indicated an uncaring firm that does not admit its faults or adequately respond to the needs of surrounding communities, thereby ultimately reneging on its duty as a responsible neighbour. The couple resorted to monitoring noise levels in the garden using their own equipment and complaining to the Environment Agency, as the permit issuer for the site, which could, for instance, impose fines on the company and force them into action.

The tensions around noise pollution in Fawley are indicative of a broader sense of frustration with Esso's contemporary forms of community engagement. In both 1997 and 2019, some residents expressed cynicism that Esso primarily communicates with local residents through public relations campaigns and updates on developments (e.g. sponsored events, technological improvements on site) to which they are ambivalent, rather than on the substantive issues associated with living in close proximity to the refinery, particularly those connected to health and safety or localised annoyances. The disconnect between Esso and the community has facilitated perceptions of the company as being secretive or mysterious, despite them opening up lines of communication with local residents. The community tours of the refinery did little to demystify the site for local residents with some participants reflecting that the tour was an exercise in public relations and that Esso would 'only show you what they want you to see' (2019 focus group discussion).

While Esso's recognition of community concerns, notably through compensation, forms an important component of enduring community-industry trust relations, the 2019 findings highlight grievances around recognition as a key point of friction. Despite the shared industrial heritage, the local population nevertheless held ongoing objections, frustrations and fears around the industry that cannot be solely addressed through compensation, the flow of 'fuel money' or public relations campaigns. Although the noise pollution incident indicates signs of eroding trust compared to previously, it may be that the disputes and grievances voiced by residents are placated by Esso's corporate re-negotiation tactics, either through the NFDC or directly with the community, similar to other risk incidents in the past

\section{Discussion and conclusion}

In Fawley, an enduring social trust in Esso has not led to a suppression or denial of local risk. Instead, the environmental and health risks associated with the Fawley refinery are perceived and understood by residents and even seen as urgent on occasions, but are justified, downplayed and reframed as being liveable with on an everyday basis, grounded in the post-war social contract. We distinguish our research findings from cases of low risk perception, drawing attention to the residents' careful, ambivalent reckoning with risks over time. Indicative of a conditional form of trust, local environmental and health threats from the refinery are assessed, calculated and navigated in relation to residents' experiential knowledge of work and life in Waterside, shared industrial heritage and enduring perceptions of Esso as a good neighbour. Esso has strived to maintain such a reputation through responding to local concerns and complaints, while falling back on its historic role as an industrial benefactor. For the most part, this strategy has served the company well for managing its relations with the community. 
Through this research, we add further nuance to debates around local acceptance of risk in polluted communities and contribute to existing understandings of the role of local knowledge in judgements about trust and risk (Irwin, 1995; Jovanović, 2018; Szerszynski, 1999). As Wynne (1992) argued in his research on sheep farmers in Cumbria, the social basis of trust in the public understanding of risk is multidimensional, delicately balanced and sometimes apparently conflicting. As indicated in other fenceline community contexts (e.g. Eaton and Kinchy, 2016), the ambivalences around environmental and health risks have had a demobilising effect in Fawley. Aside from individual grievances, the 'growing limits to trust in industry', observed by Phillimore and Bell (2005) in Ludwigschafen, have not grown in Fawley to the extent that residents would collectively oppose local industry on the basis of risk concerns. The recent arrivals to the area have not significantly disrupted the status quo, or led to stark social division around environmental degradation, unlike what has been found in other industrial communities around the world (e.g. Auyero and Swistun, 2009; Kojola, 2020).

Thus, our research findings connect to the concept of quiescence (Gaventa, 1982; Shriver et al., 2014), where some grievances around industry and risk lie 'hidden and contained' (Gaventa, 1982: 282) amid overall public trust in Esso. Drawing on the insights of Wynne (1992) and Phillimore and Bell (2005), we demonstrate that public displays of confidence can coexist in tension with private admissions of mistrust, dynamics that are managed and navigated as ways of living with habitual risks and economically rewarding and culturally defining industry. Much research on quiescence in fenceline communities highlights the role of powerlessness in keeping grievances from being voiced and interests from being recognised, rather than people necessarily consenting to their conditions (e.g. Gaventa, 1982). However, while there are indeed barriers to participation and power inequalities which exist in the case of Fawley, we foreground the importance of long-established trust in Esso - developed over a period of time and tethered to various social, cultural and economic factors - in shaping local structures of feeling around industry and risk in Waterside.

By comparing the local perceptions of Fawley inhabitants across 1997 and 2019, we were able to draw out the temporal dynamics of risk and trust in Fawley. While acknowledging the distinct methodologies employed by the two studies, the comparative research offers additional insight to studies of fenceline communities that typically offer a snapshot of the situation at one point in time. Temporal dimensions are important to explore in cases such as Fawley, polluted communities which face sustained yet uneven risks and where understandings of local risk are developed, refined and reassessed as the years pass (Bickerstaff and Simmons, 2009; Adams et al., 2018).

Strikingly, we found that little has changed in local community perceptions between the two studies. While there exist simmering frustrations, signs of unease and elements of distrust among the local population in recent times as industrial employment has gradually declined, overall the picture in 2019 was not too dissimilar from that in 1997. Despite some changes in recent times - notably increasing knowledge about the role of refinery operations in air pollution and climate change, and faltering attempts at recognition by Esso - the comparative findings indicate that local feelings around industry and risk have remained broadly intact. A cautious sense of trust in Esso as a polluting neighbour has endured in Fawley, based on a delicate balance of heritage, risk and recognition, despite the multifaceted pressure points that threatened to disturb this equilibrium.

Drawing on the concept of the 'half-life of deindustrialisation' (Linkon, 2018) and the ongoing processes of industrial ruination (Mah, 2012), we highlight the shared industrial cultures and close industry-community relations developed from the post-war years that are held onto and endure in the present. Unlike other cases of socio-economic decline and dislocation, the factories have not closed in Fawley and have been operated by the same firm since the 1950s, meaning that there has not been a clear break with the past and no clear transition to something new. Risk acceptance in Fawley remains underpinned by cultural and emotional attachments to industry, a place-based 
heritage that is actively drawn upon and amplified by Esso. With the declining economic and employment contribution of the industry, companies may exploit cultural resources to maintain legitimacy and pre-empt local criticism (Adams et al., 2020; Bell and York, 2010).

As well as the longevity of Esso's refinery operations in Fawley, a number of contextual factors help to explain why there has not been a breaking point in Fawley. First, there has not been a dramatic or notable incident at the refinery in recent times - either a large-scale accident or pollution event - nor the emergence of scientific evidence on the environmental and health effects of industrial pollution during a period when socio-economic benefits have declined, aspects which have motivated communities to act in other parts of the world. Second, the location of Waterside communities on the edge of the New Forest national park and surrounding areas of natural beauty has perhaps enabled residents to bear the environmental and health burdens of the refinery, given the dual forms of place identity and shared heritage that many hold.

Third, the relative affluence of Waterside area, with many older, retired inhabitants having received healthy retirement packages from industry (2019 interviews), means that Fawley can be distinguished from other cases where widespread socio-economic deprivation and stigma has led to a reassessment of the balance of benefits and risks by the local population (e.g. Bush et al., 2001). Fourth, it may be that the political profile of the New Forest East parliamentary constituency as a 'safe' conservative seat (UK Parliament, 2021) underpins the local acceptance of risky polluting industry, as indicated by recent research in the US (e.g. Gravelle and Lachapelle, 2015; Jerolmack and Walker, 2018). However, there was little indication of ideology or politics in the views of residents on industry and risk, meaning that the long-standing, socio-economic and cultural connections with Esso are likely a more significant factor than political allegiances in this case.

Periodic risky incidents and fears over local industrial threats associated with refinery operations have never quite destabilised trust in Esso or left a lasting mark on local attitudes towards industry and risk. Instead, a carefully balanced relationship between the community and industry has persisted for decades, indicating a remarkable tenacity of trust relations in Fawley. Reflecting the protracted nature of socio-economic change in Fawley, local views on industry and risk have been slow to change and resilient. While a single study of Fawley in either 1997 or 2019 might indicate a situation on the precipice of eruption, our longitudinal analysis highlights more evidence of continuity than change over the period of time studied in a community context marked by profound familiarity with polluting industry and normalisation of industrial risk.

\section{Highlights}

- We conduct a comparative analysis of local risk perceptions in 1997 and 2019 in the communities living adjacent to the Fawley refinery complex (UK).

- Through our longitudinal analysis, we explore the temporal dynamics of risk and trust in Fawley, distinctive from the majority of studies of industrial polluted communities that are anchored to one point in time.

- Overall, the picture in 2019 was not too dissimilar from that in 1997, with a cautious sense of trust in industry enduring.

- Local risk perceptions in Fawley are closely bound up with the residents' shared industrial heritage and enduring perceptions of Esso as a 'good neighbour'.

- We draw attention to the residents' careful reckoning with risks over time and the tenacity of social trust as an act of negotiation. 


\section{Acknowledgments}

We express our gratitude to Professor Rosemary-Claire Collard and the three anonymous reviewers for their valuable and constructive comments. We would like to thank our research participants in Fawley and the surrounding communities for giving their time and sharing their experiences with us in the 2019 study. We also thank the whole Toxic Expertise team for their support and insights during the research process, notably Lorenzo Feltrin for the feedback he provided on an earlier draft of the paper and Chris Waite for his assistance in organising the fieldwork.

We are grateful to Peter Simmons who led the research for the 1997 Fawley case study, Alan Irwin and Brian Wynne who were collaborators on this project and all of the community members who participated in the research.

An earlier version of this paper was presented at the annual Toxic Expertise workshop in 2020.

\section{Funding}

The author(s) disclosed receipt of the following financial support for the research, authorship and/or publication of this article: This work was supported by the H2020 European Research Council (Grant No. 639583).

\section{ORCID iDs}

David Brown (D) https://orcid.org/0000-0003-1256-4674

Alice Mah (iD https://orcid.org/0000-0001-8183-2527

\section{Note}

1. Local environmental NGOs have raised concerns over industrial pollution at public meetings. In June 2017, a protest urging the Church of England to divert from ExxonMobil was organized at the Fawley refinery, bringing together a coalition of faith and non-faith groups, largely as a response to Donald Trump's position on climate change.

\section{References}

Adams, AE, Shriver, TE, Saville, A, et al. (2018) Forty years on the fenceline: Community, memory, and chronic contamination. Environmental Sociology 4(2): 210-220.

Adams, AE, Shriver, TE, Bray, LA, et al. (2020) Petrochemical pollution and the suppression of environmental protest Sociological Inquiry 90(3): 646-668.

Atari, DO, Luginaah, I, \& Baxter, J (2011) "This is the mess that we are living in": Residents everyday life experiences of living in a stigmatized community. GeoJournal 76(5): 483-500.

Auyero, J, \& Swistun, DA (2009) Flammable: Environmental Suffering in an Argentine Shantytown. Oxford: Oxford University Press.

Beck, U (1992) Risk Society: Towards A New Modernity. London: Sage.

Bedford, T, \& Burgess, J (2001) The focus-group experience. In: M Limb \& C Dwyer (eds) Qualitative Methodologies for Geographers. London: Arnold, 121-135.

Bell, SE (2016) Fighting king coal: The challenges to micromobilization in central Appalachia. Cambridge, Massachusetts: MIT Press.

Bell, SE, \& York, R (2010) Community economic identity: The coal industry and ideology construction in West Virginia. Rural Sociology 75(1): 111-143.

Bickerstaff, K, \& Simmons, P (2009) Absencing/presencing risk: Rethinking proximity and the experience of living with major technological hazards. Geoforum 40: 864-872.

Bickerstaff, K, \& Walker, G (2003) The place(s) of matter: Matter out of place - public understandings of air pollution. Progress in Human Geography 27(1): 45-67. 
Boudet, H, Bugden, D, Zanocco, C, et al. (2016) The effect of industry activities on public support for 'fracking'. Environmental Politics 25(4): 593-612.

Bullard, RD (1990) Dumping in Dixie: Race, Class, and Environmental Quality. Boulder, CO: Westview Press.

Burningham, K, \& Thrush, D (2004) Pollution concerns in context: A comparison of local perceptions of the risks associated with living close to a road and a chemical factory. Journal of Risk Research 7(2): 213-232.

Bush, J, Moffatt, S, \& Dunn, C (2001) 'Even the birds round here cough': Stigma, air pollution and health in teesside. Health \& Place 7(1): 47-56.

Coolsaet, B, \& Néron, PY (2020) Recognition and environmental justice. In: B Coolsaet (eds) Environmental Justice. London: Routledge, 52-63.

Davies, T (2018) Toxic space and time: Slow violence, necropolitics, and petrochemical pollution. Annals of the American Association of Geographers 108(6): 1537-1553.

Eaton, E, \& Kinchy, A (2016) Quiet voices in the fracking debate: Ambivalence, nonmobilization, and individual action in two extractive communities (Saskatchewan and Pennsylvania). Energy Research \& Social Science 20: 22-30.

Esso UK Limited (Ltd.) (2011) Fawley refinery and petrochemical plant. Report, Esso UK Ltd, UK, September. Available at: https://www.fawleyonline.org.uk/pub/FA2011/Fawley_Achievement_2011_ FINAL.pdf (accessed 30 July 2021).

ExxonMobil (2018) Fawley Refinery and Petrochemical Plant. Available at: https://publications.exxonmobil.com/view/364606171/12/ (accessed 30 July 2021).

Gaventa, J (1982) Power and Powerlessness: Quiescence and Rebellion in an Appalachian Valley. Urbana and Chicago: University of Illinois Press.

Giddens, A (1990) The Consequences of Modernity. Cambridge: Polity Press.

Gramaglia, C (2014) No environmental justice movement in France? Controversy about pollution in two southern French industrial towns. Analyse \& Kritik 36(2): 287-314.

Gravelle, TB, \& Lachapelle, E (2015) Politics, proximity and the pipeline: Mapping public attitudes toward keystone XL. Energy Policy 83: 99-108.

Hampshire County Council (2021) Waterside rail re-opening: Strategic outline business case. Report, Hampshire County Council, UK, February.

Huber, MT (2013) Lifeblood: Oil, Freedom, and the Forces of Capital. Minneapolis: University of Minnesota Press.

Irwin, A (1995) Citizen Science: A Study of People, Expertise and Sustainable Development. London: Routledge.

Irwin, A, Simmons, P, \& Walker, G (1999) Faulty environments and risk reasoning: The local understanding of industrial hazards. Environment and Planning A 31(7): 1311-1326.

Jephcote, C, \& Mah, A (2019) Regional inequalities in benzene exposures across the European petrochemical industry: A Bayesian multilevel modelling approach. Environment International 132: 104812.

Jerolmack, C, \& Walker, ET (2018) Please in my backyard: Quiet mobilization in support of fracking in an Appalachian community. American Journal of Sociology 124(2): 479-516.

Jobin, P (2020) Our 'good neighbor' Formosa plastics: Petrochemical damage (s) and the meanings of money. Environmental Sociology 7(1): 40-53.

Johnston, J, \& Cushing, L (2020) Chemical exposures, health, and environmental justice in communities living on the fenceline of industry. Current Environmental Health Reports 7(1): 48-57.

Jovanović, D (2018) Prosperous pollutants: Bargaining with risks and forging hopes in an industrial town in eastern Serbia. Ethnos 83(3): 489-504.

Kojola, E (2020) Who speaks for the place? Cultural dynamics of conflicts over hazardous industrial development. Sociological Forum 35(3): 673-695.

Law, P (2008) Fears about Fawley. Daily Echo, 11 May. Available at: https://www.dailyecho.co.uk/news/ 2262452.fears-about-fawley/ (accessed 30 July 2021).

Lerner, S (2010) Sacrifice Zones: The Front Lines of Toxic Chemical Exposure in the United States. Cambridge, Massachusetts: MIT Press. 
Lewin, PG (2019) "Coal is not just a job, it's a way of life": The cultural politics of coal production in Central Appalachia. Social Problems 66(1): 51-68.

Linkon, SL (2018) The Half-Life of Deindustrialization: Working-Class Writing About Economic Restructuring. Ann Arbor: University of Michigan Press.

Longhurst, R (2003) Semi-structured interviews and focus groups. Key Methods in Geography 3(2): 143-156.

López-Navarro, MÁ, Llorens-Monzonís, J, \& Tortosa-Edo, V (2013) The effect of social trust on citizens' health risk perception in the context of a petrochemical industrial complex. International Journal of Environmental Research and Public Health 10(1): 399-416.

Lora-Wainwright, A (2021) Resigned Activism: Living with Pollution in Rural China. Revised edition. Cambridge, Massachusetts: MIT Press.

Luginaah, IN, Taylor, SM, Elliott, SJ, et al. (2002) Community responses and coping strategies in the vicinity of a petroleum refinery in Oakville, Ontario. Health \& Place 8(3): 177-190.

Mah, A (2012) Industrial Ruination, Community, and Place: Landscapes and Legacies of Urban Decline. Toronto: University of Toronto Press.

Mah, A, \& Wang, X (2019) Accumulated injuries of environmental injustice: Living and working with petrochemical pollution in Nanjing, China. Annals of the American Association of Geographers 109(6): 19611977.

Mayer, A (2016) Risk and benefits in a fracking boom: Evidence from Colorado. The Extractive Industries and Society 3(3): 744-753.

McAdam, D, \& Boudet, H (2012) Putting Social Movements in Their Place: Explaining Opposition to Energy Projects in the United States, 2000-2005. New York: Cambridge University Press.

Messer, CM, Shriver, TE, \& Adams, AE (2015) Collective identity and memory: A comparative analysis of community response to environmental hazards. Rural Sociology 80(3): 314-339.

Milbourne, P, \& Mason, K (2017) Environmental injustice and post-colonial environmentalism: Opencast coal mining, landscape and place. Environment and Planning A: Economy and Space 49(1): 29-46.

Neumann, P (2016) Toxic talk and collective (in) action in a company town: The case of La Oroya, Peru. Social Problems 63(3): 431-446.

New Forest District Council (NFDC) (2008) Fawley air quality action plan 2008. Report, New Forest District Council, UK.

New Forest District Council (NFDC) (2009) Core strategy: New forest district outside the National Park. Report, New Forest District Council, UK, October.

New Forest District Council (NFDC) (2018) Air quality annual status report. Report, New Forest District Council, UK, August.

New Forest District Council (NFDC) (2019) Planning Committee Report for the Proposed Fawley Site Expansion. Report, New Forest District Council, UK, September.

Nixon, R (2011) Slow Violence and the Environmentalism of the Poor. Cambridge, Massachusetts: Harvard University Press.

Office for National Statistics (ONS) (2011) Fawley Parish: Local Area Report. Available at: http://www.nomisweb.co.uk/reports/localarea?compare=E04004568 (accessed 30 July 2021).

Ordinance Survey Maps (2021). OS Maps. Available at: https://osmaps.ordnancesurvey.co.uk/ (accessed 30 July 2021).

Parkhill, KA, Pidgeon, NF, Henwood, KL, et al. (2009) From the familiar to the extraordinary: Local residents' perceptions of risk when living with nuclear power in the UK. Transactions of the Institute of British Geographers 35(1): 39-58.

Phillimore, P, \& Bell, P (2005) Trust and risk in a German chemical town. Ethnos 70(3): 311-334.

Phillimore, P, Schlüter, A, Pless-Mulloli, T, et al. (2007) Residents, regulators, and risk in two industrial towns. Environment and Planning C: Government and Policy 25(1): 73-89.

Pitkanen, L (2017) Black Wednesday: Radiation, stigma and property values. Environment and Planning A: Economy and Space 49(7): 1537-1155.

Räthzel, N, \& Uzzell, D (2011) Trade unions and climate change: The jobs versus environment dilemma. Global Environmental Change 21(4): 1215-1223. 
Schlosberg, D (2007) Defining Environmental Justice: Theories, Movements, and Nature. Oxford: Oxford University Press.

Schlüter, A, Phillimore, P, \& Moffatt, S (2004) Enough is enough: Emerging 'self-help' environmentalism in a petrochemical town. Environmental Politics 13(4): 715-733.

Sheail, J (2002) An Environmental History of Twentieth-Century Britain. Basingstoke: Palgrave.

Shriver, TE, Adams, AE, \& Messer, CM (2014) Power, quiescence, and pollution: The suppression of environmental grievances. Social Currents 1(3): 275-292.

Shriver, TE, Messer, CM, Whittington, JR, et al. (2020) Industrial pollution and acquiescence: Living with chronic remediation. Environmental Politics 29(7): 1219-1238.

Simmons, P, \& Walker, G (1999) Tolerating risk: Policy principles and public perceptions. Risk Decision and Policy 4(3): 179-190.

Szerszynski, B (1999) Risk and trust: The performative dimension. Environmental Values 8(2): 239-252.

UK Parliament (2021) New forest east. Available at: https://members.parliament.uk/constituency/3621/ location (accessed 30 July 2021).

Verbeek, T (2020) Explaining public risk acceptance of a petrochemical complex: A delicate balance of costs, benefits, and trust Environment and Planning E: Nature and Space: 1-26.

Walker, G, Simmons, P, Irwin, A, et al. (1998) Public Perception of Risks Associated with major Accident Hazards. Health and Safety Executive Research Report 194/1998. Sudbury: HSE Books.

World Health Organisation (WHO) (2014) Human Health in Areas with Industrial Contamination. Copenhagen: WHO Regional Office for Europe.

Wynne, B (1992) Misunderstood misunderstanding: Social identities and public uptake of science. Public understanding of science 1(3): 281-304.

Zonabend, F (1993) The Nuclear Peninsula. Cambridge: Cambridge University Press. 